\title{
Studies in Porphyria
}

\author{
VII. INDUCTION OF UROPORPHYRINOGEN-I SYNTHASE \\ AND EXPRESSION OF THE GENE DEFECT OF ACUTE INTERMITTENT \\ PORPHYRIA IN MITOGEN-STIMULATED HUMAN LYMPHOCYTES
}

\author{
Shigeru Sassa, Gregory L. Zalar, and Attallah Kappas, The Rockefeller \\ University Hospital, New York 10021
}

A B STRACT A $50 \%$ reduction in the activity of uroporphyrinogen-I (URO) synthase in liver, erythrocytes, and cultured skin fibroblasts characterizes all patients with clinically active acute intermittent porphyria (AIP). The same enzyme defect has also been demonstrated in the erythrocytes and skin fibroblasts of completely latent gene carriers of this disorder and presumably exists in the liver as well.

In this study, we examined whether or not the formation of URO-synthase is impaired in AIP cells using lymphocytes treated with mitogens or infected with Epstein-Barr virus. Both mitogens (phytohemagglutinin and pokeweed mitogen) and Epstein-Barr virus induced the synthesis of URO-synthase in lymphocytes, but the induction of URO-synthase in AIP lymphocytes was only $50 \%$ as compared with that in normal lymphocytes. The impaired induction of URO-synthase in AIP lymphocytes reflects a specific gene defect because AIP lymphocytes showed normal $\left[{ }^{3} \mathrm{H}\right]$ thymidine uptake into DNA, $\left[{ }^{3} \mathrm{H}\right]$ uridine uptake into RNA, and normal $\delta$-aminolevulinic acid (ALA) synthase, ALA-dehydratase, catalase activities, and heme content. Utilizing the same methodology, the ferrochelatase deficiency of hereditary erythropoietic protoporphyria could also be identified. The $K_{m}$ of the induced URO-synthase in AIP cells was identical to that of the enzyme in normal cells. The induced URO-synthase of mitogen-treated AIP lymphocytes was not accompanied by a concurrent enhanced level of ALA-synthase. Moreover, the URO-synthase deficiency in lymphocytes from actively ill AIP patients was not different from the level of enzyme activity

Doctor Zalar is a fellow in the Department of Dermatology, Columbia University College of Physicians and Surgeons, New York.

Received for publication $28 \mathrm{July} 1977$ and in revised form 10 October 1977. when they were in clinical remission, or when compared with the enzyme activity of cells from completely latent AIP gene carriers. The results of this study indicate that the URO-synthase deficiency in AIP may be the result of a gene mutation regulating the rate of synthesis of a normal enzyme rather than a mutation causing a structural abnormality of this enzyme protein.

\section{INTRODUCTION}

Acute intermittent porphyria (AIP), ${ }^{1}$ a genetic liver disease of man, is one of the few autosomal dominant disorders in which a specific biochemical defect has been characterized. A $50 \%$ deficiency of uroporphyrinogen-I (URO) synthase activity has been found in liver cells $(1,2)$ of patients with this disease, and this enzyme defect has also been identified in erythrocytes (3-6), epidermal cells (7), cultured skin fibroblasts $(8-10)$, and cultured amniotic cells (9) obtained from gene carriers of this disorder. The detection of decreased URO-syr thase activity in nonhepatic cell types has proved to be useful in the detection of the AIP gene carrier state in utero (9), or before puberty (5), and in those adults in whom AIP has remained clinically latent $(4,5)$.

URO-synthase in AIP erythrocytes is not distinguishable from the normal enzyme by its electrophoretic mobility $(3,5)$, heat denaturation curve (5), and $K_{m}(3,6)$ in a partially purified enzyme preparation. These data would suggest that the decreased URO-synthase activity in AIP is the result of diminished concentration

\footnotetext{
${ }^{1}$ Abbreviations used in this paper: AIP, acute intermittent porphyria; ALA, $\delta$-aminolevulinic acid; EB, Epstein-Barr; F-I, modified F12 medium supplemented with insulin $(1 \mu \mathrm{g} / \mathrm{ml})$; PBG, porphobilinogen; PHA, phytohemagglutinin; PROTO, protoporphyrin IX; PWM, pokeweed mitogen; URO, uroporphyrinogen-I.
} 
of the normal enzyme rather than the production of a catalytically inactive enzyme protein.

The question posed in this study was whether or not the production of URO-synthase is defective in AIP subjects as compared with normal individuals. To answer this question we have utilized lymphocytes that undergo transformation and metabolic activation after treatment with the mitogens phytohemagglutinin (PHA) or pokeweed mitogen (PWM), or infection with Epstein-Barr (EB) virus. The results of this study indicate that URO-synthase can be induced in lymphocytes as much as 30-fold by mitogen treatment and that the induced level of URO-synthase in AIP lymphocytes is on average approximately one-half the level in normal lymphocytes. This finding suggests that the low URO-synthase activity in AIP cells is the result of a defect in the regulation of this enzyme formation.

\section{METHODS}

Materials. $\delta$-Aminolevulinic acid (ALA) hydrochloride and crystalline bovine insulin were purchased from Sigma Chemical Co. (St. Louis, Mo.). Porphobilinogen (PBG) was a gift from Dr. Vogelmann, GMB Forschung, Braunschweig, West Germany. A modified F12 medium supplemented with insulin (F-I)(11) was prepared in our laboratory. Fetal bovine serum, PHA, and PWM were obtained from Grand Island Biological Co. (Grand Island, N. Y.). Lymphoprep $(5.6 \%$ [wt/vol] Ficoll-9.6\% [wt/vol] sodium metrizoate) solution was obtained from Accurate Chemical \& Scientific Corp. Hicksville, N. Y. Plastic culture flasks and tubes were products of Falcon Plastics (Div. BioQuest, Oxnard, Calif.).

Subjects studied. Nine female patients with clinically manifest AIP (low URO-synthase in erythrocytes, excessive urinary ALA and PBG excretion, and clinical symptoms) as well as nine latent AIP gene carriers (low URO-synthase in erythrocytes, normal urinary ALA and PBG, and no clinical symptoms ever having been expressed) were studied. The latter group included five males and four females. The age range was 27-66 yr for the clinically active patients and 12-63 yr for the latent AIP gene carriers. 13 normal subjects $(5$ males, 8 females) with ages ranging from 4 to $60 \mathrm{yr}$ were also studied as controls.

Cell culture. All cultures were prepared under sterile conditions. Each cell preparation from an AIP subject was studied with a normal control preparation in each experiment. Lymphocyte concentrates were prepared by isopyknic sedimentation as follows: Approximately $30 \mathrm{ml}$ of venous blood was withdrawn in a syringe without any additive and immediately defibrinated by rotation in a 250 -ml Erlenmeyer flask containing 30 glass beads (ca. 6-mm diameter). Defibrinated blood was diluted with 1 vol of the culture medium. $8 \mathrm{ml}$ of the diluted blood was overlayed on a 6-ml Lymphoprep solution (specific gravity $1.077 \pm 0.001 \mathrm{~g} / \mathrm{ml}$ ) in a $17 \times 100-\mathrm{mm}$ polystyrene Falcon tube (Falcon Plastics). The tubes were centrifuged at $400 \mathrm{~g}$ for $30 \mathrm{~min}$ at room temperature, and the lymphocyte-rich interphase fraction was collected and transferred to a $50-\mathrm{ml}$ conical centrifuge tube. $30 \mathrm{ml}$ of the medium was added, and the tubes were centrifuged again at $400 \mathrm{~g}$ for 5 min to sediment the cells. The cell pellet was resuspended in $5 \mathrm{ml} \mathrm{NH}{ }_{4} \mathrm{Cl}$ :Tris $\mathrm{HCl}: \mathrm{KHCO}_{3}$ solution for $5 \mathrm{~min}$ to hemolyze contaminating red cells (11). The cell pellet was washed twice with $5 \mathrm{ml}$ of the culture medium and finally suspended in the medium supplemented with $10 \%$ heat-inactivated fetal bovine serum, containing penicillin $100 \mu \mathrm{g} / \mathrm{ml}$, streptomycin $100 \mu \mathrm{g} / \mathrm{ml}, 1 \mathrm{vol}$ percent of PHA and PWM and $20 \mathrm{U} / \mathrm{ml}$ of heparin disodium. To minimize possible variations, single batches of the culture medium and fetal bovine serum were used throughout the study. The final cell concentration was adjusted to $5 \times 10^{5}$ cells $/ \mathrm{ml}$ unless otherwise noted. Usually a $40 \sim 50$-ml cell suspension, containing a total of $2 \sim 2.5 \times 10^{7}$ cells, was obtained from a single subject. Differential counts of smears stained with Wright-Giemsa showed less than two granulocytes and 10 erythrocytes per 1,000 nucleated cells. This cell suspension was transferred into $12 \times 100-\mathrm{mm}$ Falcon tubes ( $1 \mathrm{ml} /$ tube) or $30-\mathrm{ml}$ Falcon flasks $(5 \mathrm{ml} /$ flask) and incubated at $37^{\circ} \mathrm{C}$ for $96 \mathrm{~h}$ in an atmosphere of $5 \% \mathrm{CO}_{2}$ and $100 \%$ relative humidity.

To establish continuous cultures of human lymphocytes, cells obtained from six AIP subjects (three clinically active, and three latent subjects) were infected with $\mathrm{EB}$ virus. Two normal controls were also studied. EB virus infection of lymphocytes was kindly performed by Dr. A. Greene, Institute for Medical Research, Camden, N. J. EB virus-infected cultures were maintained at a cell density of $2 \sim 10 \times 10^{5}$ cells $/ \mathrm{ml}$ in the culture medium supplemented with $10 \%$ fetal bovine serum and were transferred into a new medium twice weekly. Assays were made on cultures maintained for a 2- to 3-mo period. Human skin fibroblasts were cultured as described previously (9).

\section{Assays}

Porphyrin formation. After 4 days of incubation in the presence of mitogens, the cells in $12 \times 100$ Falcon tubes ( $1 \mathrm{ml} /$ tube) were centrifuged and washed twice with $1 \mathrm{ml}$ of serum-free F-I medium. This medium (devoid of serum and phenol red) was found earlier to be more effective than a serum-containing medium in supporting the formation of porphyrins and inhibiting release of porphyrins into growth medium from cultured skin fibroblasts (5). These findings were confirmed in lymphocytes. Cells were suspended in $1 \mathrm{ml}$ F-I medium containing ALA $(0.6 \mathrm{mM})$ and CaMg EDTA $(5 \mathrm{mM})$ and incubated for $24 \mathrm{~h}$ at $37^{\circ} \mathrm{C}$ in a $5 \% \quad \mathrm{CO}_{2}$ atmosphere.

At the end of incubation, cells were collected by centrifugation at $600 \mathrm{~g}$ for $5 \mathrm{~min} .500 \mu \mathrm{l}$ of $0.5 \mathrm{~N}$ perchloric acid- $50 \%$ methanol solution was added to the cell pellet, and the tube agitated vigorously. This mixture was then centrifuged at $600 \mathrm{~g}$ for $5 \mathrm{~min}$, and the supernate was transferred into a $6 \times 50-\mathrm{mm}$ glass test tube. A fluorescence emission spectrum of the extract was obtained in these glass tubes using a semimicrocell holder (5) in a Hitachi Perkin-Elmer MPF III fluorescence spectrophotometer (Perkin-Elmer Corp., Mountain View, Calif.) equipped with a red sensitive photomultiplier (No. 777-01). Coproporphyrin $\left(10^{-7} \mathrm{M}\right)$ in $0.5 \mathrm{~N}$ perchloric acid-50\% methanol served as a standard.

500,000 cells were washed twice with Earle's buffer and were dissolved in $200 \mu \mathrm{l}$ of $0.2 \mathrm{~N} \mathrm{NaOH}$ by heating at $60^{\circ} \mathrm{C}$ for $30 \mathrm{~min}$. Protein concentration was determined by the method of Lowry et al. (12). Crystalline bovine serum albumin was used as standard assuming the absorbance of a $1 \%$ solution at $280 \mathrm{~nm}$ to be 6.60 (13). Smear preparations of cells were also made and stained with Wright-Giemsa stain for morphological observations.

URO-synthase assay. The assay of URO-synthase activity was performed by the semimicrofluorometric method described earlier (5). 500,000 cells were suspended in $25 \mu \mathrm{l}$ of $100 \mu \mathrm{M}$ PBG in $0.1 \mathrm{M}$ phosphate buffer (pH 7.4) and frozen-thawed three times before incubation. The frozenthawed mixture was incubated at $37^{\circ} \mathrm{C}$ for $1 \mathrm{~h}$ in subdued light. 
The reaction was terminated by the addition of $300 \mu$ l of ethyl acetate-acetic acid $(2: 1, \mathrm{vol} / \mathrm{vol})$ which also served to extract porphyrins and heme from the reaction mixture. Then $300 \mu \mathrm{l}$ of $0.5 \mathrm{~N} \mathrm{HCl}$ was added, and the tube was shaken vigorously to extract porphyrins into the aqueous phase. Approximately $70-75 \%$ of the reaction product was identified to be URO for both normal and AIP lymphocytes as assessed by solvent extraction (14) and by the analysis of fluorescence emission spectra of the product (15). The fluorescence emission peak at $656 \mathrm{~nm}$ in the aqueous extract was determined in a HitachiPerkin Elmer MPF III fluorescence spectrophotometer using an excitation wavelength of $400 \mathrm{~nm}$.

ALA-dehydratase assay. ALA-dehydratase was determined in $10^{6}$ cells by the semimicrocolorimetric assay described previously (16). The enzyme incubation period was $2 \mathrm{~h}$ at $37^{\circ} \mathrm{C}$.

ALA-synthase assay. ALA-synthase activity was assayed in $10^{6}$ cells by a radiochemical method described previously (17).

Heme determination. Heme content was determined in $10^{5}$ cells which were prewashed twice with $1 \mathrm{ml}$ Earle's buffer salt solution devoid of $\mathrm{Ca}$ and $\mathrm{Mg}$, by the fluorometric method previously described (17).

Catalase assay. The activity of catalase was assayed spectrophotometrically according to Baudhuin et al. (18) with the following modifications: Before the assay, $10^{6}$ cells which had been washed with Earle's buffer salt solution were suspended in $10 \mu \mathrm{l}$ of $2 \%$ (wt/vol) Triton X-100 to release the enzyme. Cells were then incubated at $0^{\circ} \mathrm{C}$ for $10 \mathrm{~min}$ in an assay mixture containing in a volume of $500 \mu \mathrm{l}$ imidazole- $\mathrm{HCl}$ buffer, pH $7.0(20 \mathrm{mM})$, bovine serum albumin $(0.1 \%)$, and hydrogen peroxide $(0.9 \mathrm{mM})$. The reaction was terminated by the addition of $300 \mu \mathrm{l}$ of a three-fold dilution of a saturated solution of titanium oxysulfate in $2 \mathrm{~N} \mathrm{H}_{2} \mathrm{SO}_{4}$ and the remaining hydrogen peroxide was determined colorimetrically as the yellow peroxy-titanium sulfate. The reaction followed firstorder kinetics up to the destruction of $90 \%$ of the substrate under these conditions. $1 \mathrm{U}$ of catalase activity is defined as the amount of enzyme catalyzing the destruction of $90 \%$ of the substrate in $1 \mathrm{~min}$ in a volume of $50 \mathrm{ml}$ under these assay conditions (16).

$\left[{ }^{3} \mathrm{H}\right]$ Thymidine and $\left[{ }^{3} \mathrm{H}\right]$ uridine incorporation into nucleic acids. 500,000 cells were incubated in $500 \mu \mathrm{l}$ of the culture medium containing $10 \%$ fetal bovine serum and 0.5 $\mu \mathrm{Ci}\left[{ }^{3} \mathrm{H}\right]$ thymidine or $\left[{ }^{3} \mathrm{H}\right]$ uridine for 0 and $4 \mathrm{~h}$ at $37^{\circ} \mathrm{C}$. At the end of incubation, 4 portions of $100 \mu$ l of each cell suspension were applied onto $22-\mathrm{mm}$ glass fiber disks (Nuclepore prefilter disks; Nuclepore Corp., Pleasanton, Calif.) and dried with warm air. The disks were immersed once in cold $10 \%$ trichloracetic acid and twice in 5\% trichloracetic acid for a minimum of 2 hours each and then incubated at $37^{\circ} \mathrm{C}$ for $30 \mathrm{~min}$ in an ethyl ether-ethanol mixture (1:1, vol/vol) and washed twice in ethyl-ether for $15 \mathrm{~min}$ to remove trichloracetic acid, and then air-dried. Each disk was placed in a liquid scintillation counting vial and treated with $0.3 \mathrm{ml}$ NCS solubilizer (Amersham/Searle Corp., Arlington Heights, Ill.) at $37^{\circ} \mathrm{C}$ for $30 \mathrm{~min} .10 \mathrm{ml}$ of Aquasol-2 (New England Nuclear, Boston, Mass.) scintillation cocktail was added to each vial, and the contents were mixed. Samples were then counted in a Packard Tricarb liquid scintillation counter (Packard Instrument Co., Inc., Downers Grove, Ill.) equipped with an absolute activity analyzer.

\section{RESULTS}

Induction of URO-synthase activity by mitogens. The basal levels of URO-synthase activity in unstimulated normal and AIP lymphocytes were measurable but were indistinguishable from each other. This is probably due to the extremely low levels of the enzyme activity which do not permit an accurate comparison between unstimulated normal and AIP lymphocytes. However, under mitogen stimulation the difference in URO-synthase activity between AIP and normal cells became expressed. An example of this is shown in Fig. 1. URO-synthase activity in the normal lymphocyte preparation studied reached $\sim 7 \mathrm{pmol} \mathrm{URO} / 10^{6}$ cells $/ \mathrm{h}$ at $37^{\circ} \mathrm{C}$ after mitogen treatment for 4 days-approximately 30 -fold over the basal level, whereas induced URO-synthase activity in the AIP lymphocyte preparation was only $2 \mathrm{pmol} \mathrm{URO} / 10^{6}$ cells $/ \mathrm{h}$ at $37^{\circ} \mathrm{C}$. The mean value of URO-synthase activity in both clinically active AIP patients ( 7 subjects) and latent gene carriers (8 subjects) in the 4-day mitogen-stimulated lymphocytes was approximately one-half compared with the normal mean value ( 13 subjects) as shown in Table $\mathrm{I}$. The $K_{m}$ of URO-synthase in an AIP lymphocyte preparation was approximately $6 \mu \mathrm{M}$ (Fig. 2) and equal to that of a normal lymphocyte preparation. The $K_{m}$ of URO-synthase partially purified from erythrocytes was also reported to be $6 \mu \mathrm{M}$ by Strand et al. (3) but it was 14 $\mu \mathrm{M}$ in crude red cell hemolysates as reported by Magnussen et al. (6). The reason for the difference in the latter finding from those of this laboratory and that of Strand et al. (3) is not known. There was some overlap of URO-synthase activities in lymphocytes from AIP and normal subjects as was previously observed with erythrocytes (5); however, the ratios of all AIP-normal pairs were substantially less variable and always distinguished AIP preparations from normal.

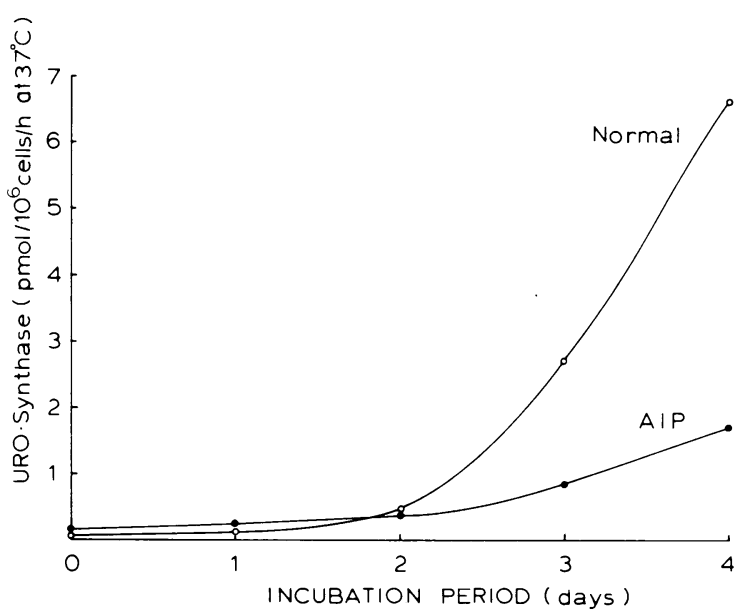

FIGURE 1 Induction of URO-synthase in mitogen-stimulated lymphocytes. URO-synthase activity was determined fluorometrically using $5 \times 10^{5}$ cells per assay and PBG as the substrate. Lymphocytes were incubated with the mitogens before the assay, and the enzyme activity is displayed as a function of incubation period with the mitogens. Points are the mean of triplicate determinations. 
TABLE I

URO-Synthase Activity in Mitogen-Stimulated Lymphocytes

\begin{tabular}{lccc}
\hline Subject & $\begin{array}{c}\text { Number } \\
\text { of } \\
\text { subjects }\end{array}$ & $\begin{array}{c}\text { URO-synthase (pmol } \\
\text { URO/mg protein/ } \\
\left.\text { h at } 37^{\circ} \mathrm{C}\right)\end{array}$ & $\begin{array}{c}\text { Ratio: } \\
\text { AIP to } \\
\text { normal }^{*}\end{array}$ \\
\hline & & Mean \pm SEM & Mean \pm SEM \\
$\begin{array}{l}\text { Normal } \\
\text { AIP (clinically } \\
\text { manifest) }\end{array}$ & 73 & $40.3 \pm 5.8$ & - \\
$\begin{array}{c}\text { AIP (latent gene } \\
\text { carriers }\end{array}$ & 8 & $17.4 \pm 3.9(P<0.02)$ & $0.48 \pm 0.05$ \\
\hline
\end{tabular}

Cells were incubated for 4 days with the mitogens before URO-synthase assay. URO-synthase assay was determined fluorometrically using PBG as the substrate.

${ }^{*}$ In each set of experiments, a ratio of an AIP value over a normal value was determined. The mean and SEM values shown were calculated from these individual ratios. There is no significant difference of the ratios: AIP to normal between clinically active patients and latent AIP gene carriers.

Porphyrin formation. Because of variation observed in the direct URO-synthase assay, we also investigated the production of porphyrins by lymphocytes incubated with ALA with the idea that, as with cultured skin fibroblasts (9), porphyrin production from ALA in AIP lymphocytes might correlate with the deficient activity of these cells. The maximum formation of porphyrins from ALA was shown to occur between 0.6-1.2 $\mathrm{mM}$ in both AIP and normal lymphocytes after incubation with the mitogens for 4 days (Fig. 3 A). Porphyrin formation was linear for $48 \mathrm{~h}$ (Fig. 3 B). CaMgEDTA, an inhibitor of ferrochelatase,

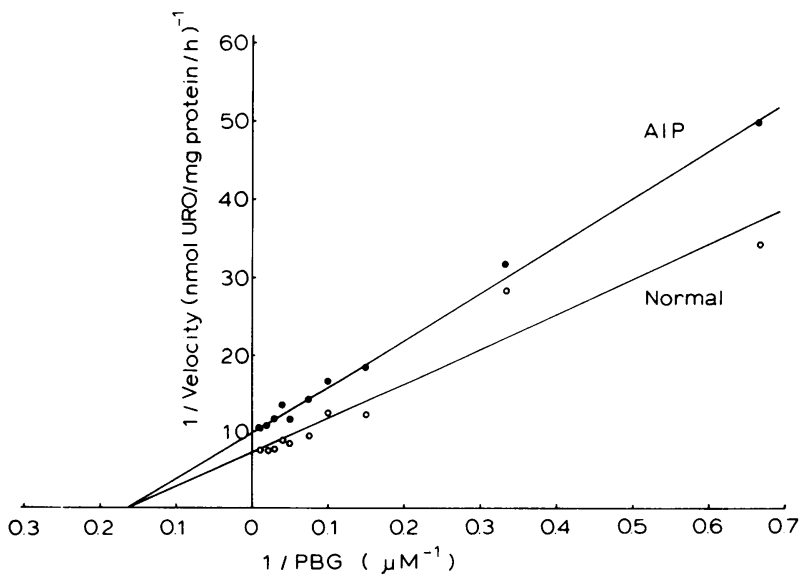

FIGURE 2 A double-reciprocal plot of URO-synthase activity. Lymphocytes were incubated with the mitogens for 4 days before the URO-synthase assay. Kinetic plots were determined by linear least square analysis. The apparent $K_{m}$ value for the substrate PBG is $6 \times 10^{-6} \mathrm{M}$ for both normal and AIP lymphocyte preparations. was shown earlier to markedly increase porphyrin formation from ALA in cultured chick embryo liver cells (11) and cultured skin fibroblasts (unpublished observations). Similarly, CaMgEDTA substantially increased porphyrin formation in activated lymphocytes (19).

Porphyrin formation from ALA also increased in lymphocytes treated with PHA and PWM as a function of the incubation time with the mitogens (Fig. 4). As with the induction of URO-synthase activity, the maximally induced level of porphyrins was found in
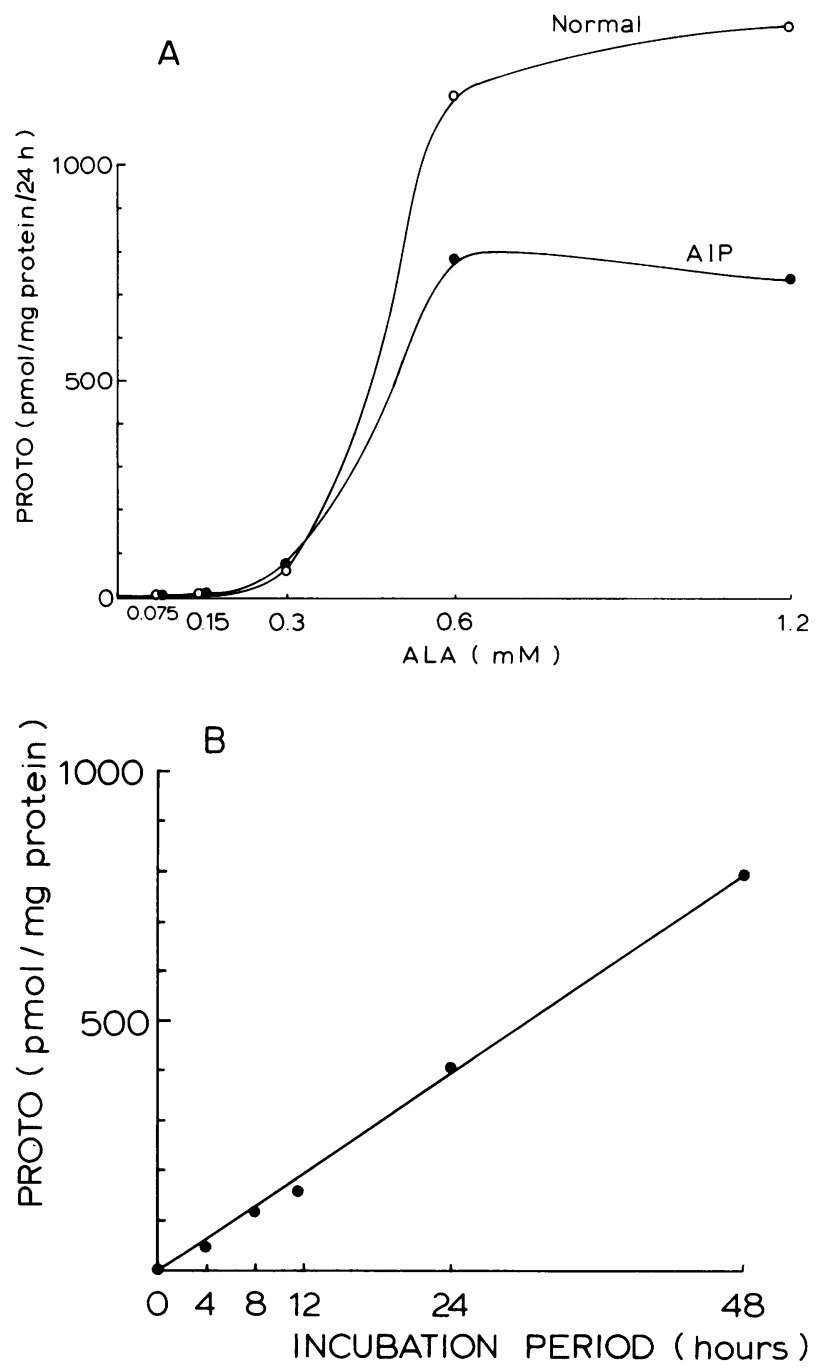

FIGURE 3 Protoporphyrin IX (PROTO) formation from ALA as a function of ALA concentration (A), and incubation period (B). Lymphocytes were preincubated with the mitogens for 4 days in each experiment. (A) Cells were incubated for 24 hours with various ALA concentrations. Normal (O): AIP (O). (B) Cells were incubated with $0.6 \mathrm{mM}$ ALA for different time periods. PROTO concentrations were determined fluorometrically using $5 \times 10^{5}$ cells per assay. Each data point represents the mean of duplicate determinations. 


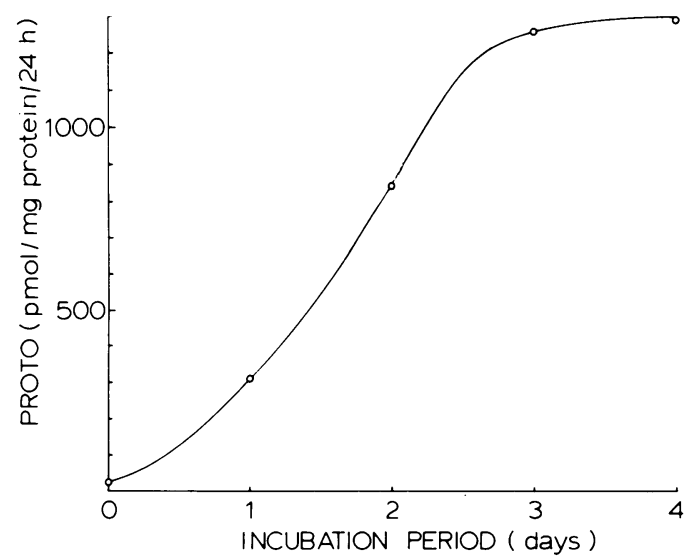

FIgURE 4 PROTO formation as a function of incubation period with mitogens. Lymphocytes from a normal subject were incubated with the mitogens, and PROTO formation from ALA is shown as a function of incubation time.

lymphocytes after the 4th day of incubation. Porphyrin formation was highest when $0.5 \sim 1 \%$ PHA was used together with $1 \%$ PWM. Porphyrin formation was also affected by the cell number in the culture and was maximal when the cell number was between 0.1 $\sim 1.0 \times 10^{6} \mathrm{cells} / \mathrm{ml}$.

The fluorescence emission spectra of cells extracted with perchloric acid-methanol indicated that essentially all of the porphyrin formed under these conditions was protoporphyrin-IX (PROTO). The maximum level of PROTO formation was 1,496 , the mean being $1,056 \pm 67 \mathrm{pmol} / \mathrm{mg}$ protein $/ 24 \mathrm{~h}$ at $37^{\circ} \mathrm{C}$ for 13 normal subjects (Table II). The maximum level of PROTO formation was 791 with the mean being $503 \mathrm{pmol} \mathrm{PROTO} / \mathrm{mg}$ protein $/ 24 \mathrm{~h}$ at $37^{\circ} \mathrm{C}$ for nine AIP patients. These values are approximately twofold higher than those found in cultured skin fibroblasts for each group (9). The difference in PROTO formation between normal and AIP groups was not demonstrable with concentrations of ALA below $0.5 \mathrm{mM}$ or until cells accumulated a larger amount of PROTO (Fig. 3 A). The greatest variation found in a normal individual on four different occasions over a 3-mo period was between $860 \sim 1,200 \mathrm{pmol}$ PROTO-mg protein $/ 24 \mathrm{~h}$ at $37^{\circ} \mathrm{C}$. Other subjects showed below $15 \%$ variations. These variations are substantially smaller than those using the direct URO-synthase assay in keeping with our previous findings with cultured skin fibroblasts (9). The mean level of PROTO formation in three AIP patients in relapse was not significantly different from the value when the same patients were in remission (Table II). Nine completely latent AIP gene carriers showed PROTO values ranging from 324 to 759 with the mean being 486 (Table II). These values are not significantly different from those of clinically active AIP patients. The value of PROTO formation by one prepubertal
TABLE II

PROTO Formation from ALA by MitogenStimulated Lymphocytes

\begin{tabular}{lcr}
\hline \multicolumn{1}{c}{ Subject } & $\begin{array}{c}\text { Number } \\
\text { of } \\
\text { subjects }\end{array}$ & $\begin{array}{c}\text { PROTO for- } \\
\text { mation (pmol } \\
\text { PROTO/mg } \\
\text { protein/24 h) }\end{array}$ \\
\hline $\begin{array}{l}\text { Normal } \\
\begin{array}{l}\text { AIP with clinical history but in } \\
\text { remission }\end{array}\end{array}$ & 13 & $1,056 \pm 67$ \\
$\begin{array}{l}\text { AIP in acute attack } \\
\text { AIP with no clinical history but with } \\
\text { low erythrocyte URO-synthase } \\
\text { activity }\end{array}$ & 9 & $503 \pm 57$ \\
\hline
\end{tabular}

Lymphocytes were incubated with the mitogens for 4 days before the addition of ALA. PROTO formation was determined in the cells incubated in F-I medium containing 0.6 $\mathrm{mM}$ ALA and $5 \mathrm{m.M}$ CaMgEDTA. Porphyrin assays were carried out fluorometrically $24 \mathrm{~h}$ after the incubation with ALA.

* These three patients in acute attacks were studied again during their remission, and these data are included in the group of nine active AIP patients in remission.

latent AIP gene carrier was 759 . This prepubertal subject was described previously (5) and continues under treatment by her neurologist with phenobarbital and diphenylhydantoin for the control of grand mal seizures. She has never displayed biochemical signs or clinical symptoms of AIP although her erythrocytes and her mitogen-stimulated lymphocytes show low UROsynthase activity.

Response to porphyrinogenic chemicals. The effects of chemicals that are potent inducers of ALAsynthase in cultured avian embryonic liver cells were studied in mitogen-stimulated lymphocytes. Allylisopropylacetamide $(100 \mu \mathrm{g} / \mathrm{ml})$, the $5 \beta-\mathrm{H}$ steroid, etiocholanolone $(4 \mu \mathrm{g} / \mathrm{ml})$, and 3,5-dicarbethoxy-1,4-dihydrocollidine $(4 \mu \mathrm{g} / \mathrm{ml})$, did not induce the formation of detectable quantities of porphyrins in the cells (data not shown). These chemicals similarly do not induce porphyrins in cultured skin fibroblasts or amniotic cells $(9,20)$.

$\left[{ }^{3} \mathrm{H}\right]$ Thymidine incorporation into DNA. The $24-\mathrm{h}$ time-courses of $\left[{ }^{3} \mathrm{H}\right]$ thymidine incorporation into one AIP and one normal cell preparation (pretreated with the mitogens for 4 days) are shown in Fig. 5. The rate of incorporation was equal in both cell cultures. Cells pretreated with the mitogens for 4 days were incubated for only $4 \mathrm{~h}$ with $\left[{ }^{3} \mathrm{H}\right]$ thymidine in subsequent experiments. 11 normal and 8 AIP ( 4 active and 4 latent) subjects were studied in this fashion. There was no significant difference in $\left[{ }^{3} \mathrm{H}\right]$ thymidine uptake into DNA between these groups (Table III). $\left[{ }^{3} \mathrm{H}\right]$ Uridine 


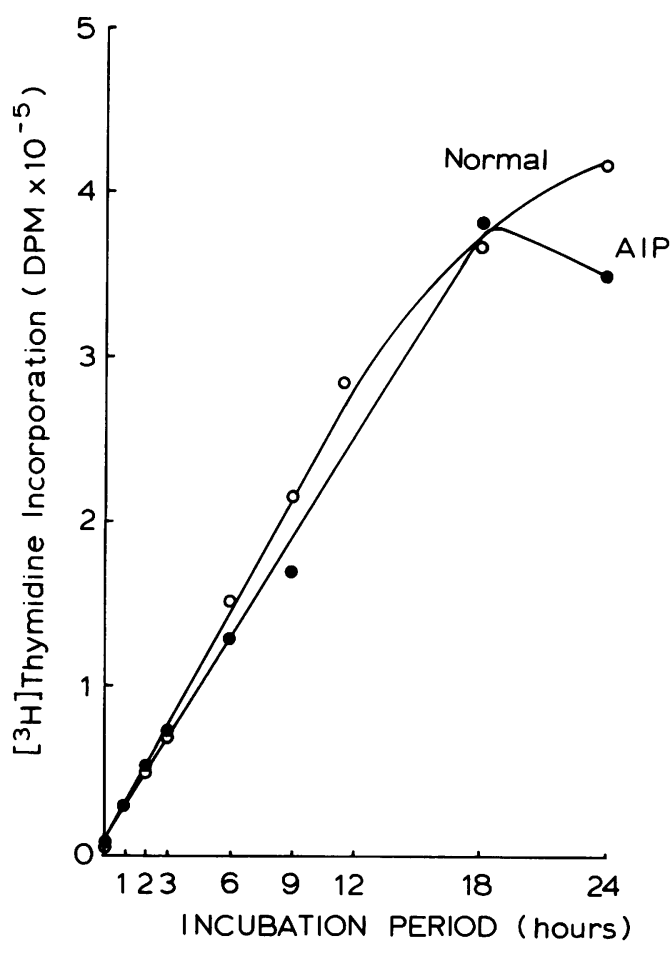

FIGURE $5 \quad\left[{ }^{3} \mathrm{H}\right]$ Thymidine incorporation into DNA. $10^{5}$ Lymphocytes which had been preincubated with the mitogens for 4 days were used to determine $\left[{ }^{3} \mathrm{H}\right]$ thymidine incorporation into DNA. Each data point represents the mean of four determinations. Normal (O); AIP (৩).

incorporation into RNA was also studied similarly in two pairs of normal and AIP subjects, and no differences in uptake were observed (data not shown).

Effect of mitogens on cultured skin fibroblasts. To determine whether or not the mitogen induction of URO-synthase and PROTO formation was a specific effect for lymphocytes, the same concentrations of PHA and PWM were added to cultured skin fibroblasts

TABLE III

$\left[{ }^{3} \mathrm{H}\right]$ Thymidine Incorporation into DNA in MitogenStimulated Lymphocytes

\begin{tabular}{lcc}
\hline Subject & $\begin{array}{c}\text { Number of } \\
\text { subjects }\end{array}$ & $\begin{array}{c}{\left[{ }^{3} \mathrm{H}\right] \text { Thymidine incorporation into }} \\
\text { DNA (DPM/10 cells/4 h) }\end{array}$ \\
\hline & & Mean \pm SEM \\
Normal & 11 & $15,443 \pm 1,457$ \\
AIP & 8 & $14,772 \pm 2,041$
\end{tabular}

Cells were incubated with the mitogens for 4 days before the addition of $\left[{ }^{3} \mathrm{H}\right]$ thymidine. Cells were incubated with $\left[{ }^{3} \mathrm{H}\right.$ ] thymidine $(1 \mu \mathrm{Ci} / \mathrm{ml})$ for $4 \mathrm{~h}$ at $37^{\circ} \mathrm{C}$ in a $\mathrm{CO}_{2}$ incubator, and $\left[{ }^{3} \mathrm{H}\right]$ thymidine incorporation into DNA was analyzed as described in the text. Four determinations were made for each cell preparation. There was no significant difference between normal and AIP groups.

\section{TABLE IV \\ Effect of Mitogens on PROTO Formation from ALA in Cultured Skin Fibroblasts}

\begin{tabular}{|c|c|c|c|}
\hline $\begin{array}{c}\text { Skin fi- } \\
\text { broblasts }\end{array}$ & Treatment & $\begin{array}{l}\text { Number of } \\
\text { samples }\end{array}$ & $\begin{array}{c}\text { PROTO formation } \\
\text { (pmol/mg protein/ } \\
24 \mathrm{~h} \text { ) }\end{array}$ \\
\hline & & & Mean $\pm S E M$ \\
\hline \multirow[t]{2}{*}{ Normal } & -PHA, -PWM & 4 & $692 \pm 25$ \\
\hline & $\begin{array}{l}+1 \% \text { PHA + } 1 \% \text { PWM, } \\
4 \text { days }\end{array}$ & 4 & $655 \pm 40$ \\
\hline \multirow[t]{2}{*}{ AIP } & -PHA, -PWM & 4 & $174 \pm 5$ \\
\hline & $\begin{array}{l}+1 \% \text { PHA + } 1 \% \text { PWM } \\
4 \text { days }\end{array}$ & 4 & $190 \pm 24$ \\
\hline
\end{tabular}

Skin fibroblasts were grown in F12-10\% fetal bovine serum. Cells were washed with F-I medium (a modified F12-medium supplemented with $1 \mu \mathrm{g}$ insulin/ml). ALA $(0.6 \mathrm{mM})$ was then added to the cultures, and PROTO formation was determined fluorometrically. Mitogen treatment of cells was made in the same manner as for lymphocyte culture.

obtained from two normal and two AIP subjects. In all four test preparations, the addition of the mitogens for 4 days to the cultured cells did not significantly influence PROTO formation from ALA (Table IV).

URO-synthase activity in EB virus-infected lymphocytes. URO-synthase activity as well as PROTO formation from ALA of EB-transformed lymphocytes were determined. The results are summarized in Table V. The mean values of URO-synthase and PROTO formation were comparable to those found in mitogen-stimulated lymphocytes. The values for EB virus-infected AIP lymphocytes were approximately one-half the normal, confirming that the gene defect of URO-synthase is also present in the virus-transformed lymphocytes from AIP gene carriers. ALA-dehydratase activity was also assayed in these lymphocytes, and there was no significant difference between normal and AIP cells (data not shown).

Levels of ALA-synthase, ALA-dehydratase, catalase,

TABLE V

URO-Synthase Activity in EB Virus-Infected Lymphocytes

\begin{tabular}{lcc}
\hline Subject & $\begin{array}{c}\text { URO-synthase } \\
(\mathrm{pmol} / \mathrm{mg} \text { protein/h) }\end{array}$ & $\begin{array}{c}\text { PROTO formation } \\
(\mathrm{pmol} / \mathrm{mg} \text { protein/24 } \mathrm{h})\end{array}$ \\
\hline Mean \pm SEM & Mean \pm SEM \\
Normal & $68.4 \pm 16.6(2)$ & $847 \pm 13(2)$ \\
AIP & $28.6 \pm 6.3(6)$ & $409 \pm 70(4)$ \\
\hline
\end{tabular}

Lymphocytes were infected with EB virus and cultured without mitogens. Assays were made on cells grown for 2-3 mo as described in the text. Figures in parentheses indicate the number of subjects used for the study. 
TABLE VI

Levels of ALA-Synthase, ALA-Dehydratase, Catalase, and Heme in Mitogen-Stimulated Lymphocytes

\begin{tabular}{ccc}
\hline & Normal & AIP \\
\hline & Mean \pm SEM & Mean \pm SEM \\
ALA-synthase ( pmoll & & \\
mg protein/30 min) & $388 \pm 20(3)$ & $250 \pm 58(4)$ \\
ALA-dehydratase & & \\
$\quad(p m o l / m g$ protein/h) & $1,933 \pm 158(8)$ & $2,020 \pm 235(10)$ \\
Catalase $\left(m U / 10^{6}\right.$ cells $)$ & $58 \pm 7(5)$ & $65 \pm 13(5)$ \\
Heme $\left(p m o l / 10^{5}\right.$ cells $)$ & $0.65 \pm 0.11(5)$ & $0.62 \pm 0.07(8)$ \\
\hline
\end{tabular}

Assays on enzyme activity and heme content were made using lymphocytes incubated with the mitogens for 4 days. Figures in parentheses indicate the number of subjects studied. Enzyme assays were conducted at $37^{\circ} \mathrm{C}$ except for catalase as noted in Methods.

and heme content in mitogen-stimulated lymphocytes. The results of ALA-synthase, ALA-dehydratase, heme, and catalase assays in mitogen-stimulated lymphocytes are summarized in Table VI. ALA-synthase, ALA-dehydratase, catalase activities, and heme contents did not distinguish AIP cells from normal controls. In contrast to the marked induction of URO-synthase in mitogen-stimulated lymphocytes $(10 \sim 15$-fold in AIP lymphocytes and $\sim 30$-fold in normal lymphocytes), the levels of ALA-synthase, ALA-dehydratase, and catalase activities were increased only two- to three-fold in response to the mitogen treatment for 4 days.

\section{DISCUSSION}

This study demonstrates for the first time that UROsynthase, an important enzyme in the heme pathway and the site of the gene defect in AIP, can be markedly induced as a result of mitogen treatment of human lymphocytes. Moreover, the gene defect of AIP, URO-synthase deficiency can be elicited in lymphocytes undergoing mitogen-induced transformation, and the activity of this induced enzyme serves to clearly distinguish AIP from normal cells. The maximum level of URO-synthase induction in AIP lymphocytes is only $50 \%$ of that found in normal lymphocytes, a finding similar to the $50 \%$ deficiency of URO-synthase found in liver cells $(1,2)$, erythrocytes (3-6), cultured skin fibroblasts (8-10), and amniotic cells (9) derived from AIP gene carriers. The deficient induction of UROsynthase activity is not the result of a difference in the extent of mitogenic transformation of AIP lymphocytes because their DNA and RNA synthetic rates are equivalent to those of normal lymphocytes. Moreover, the activities of ALA-synthase, ALA-dehydratase, and catalase as well as the heme content of AIP lymphocytes are similar to those of normal cells. These facts indicate that the deficient induction of URO-synthase activity in AIP lymphocytes is the expression of a specific gene defect which characterizes these cells.

URO-synthase activity of unstimulated lymphocytes from AIP gene carriers was indistinguishable from that of normal lymphocytes. This is probably due to the extremely low levels of the enzyme activity in unstimulated cells which prevent an accurate comparison of AIP and normal enzyme levels, but this observation is in contrast to previous findings with liver cells, erythrocytes, cultured skin fibroblasts, or amniotic cells from AIP gene carriers. On the other hand, URO-synthase activity could be induced markedly in both normal and AIP lymphocytes by mitogens, and in the induced state a deficient rate of synthesis of URO-synthase in AIP cells became manifest. Although the levels of ALA-synthase and ALA-dehydratase are higher than the levels of URO-synthase in lymphocytes, the decreased URO-synthase activity of AIP lymphocytes is not rate-limiting for heme formation, because stimulated AIP lymphocytes accumulated protoporphyrin when incubated with ALA, thus suggesting that ferrochelatase becomes rate-limiting under these conditions. It should be noted that the URO-synthase induction in lymphocytes by mitogen treatment is relatively selective because other enzymes, i.e., ALAsynthase, ALA-dehydratase, underwent only a small induction response (three- to fivefold) as compared to the potent induction response of URO-synthase. The reason(s) for the relatively specific induction of UROsynthase in lymphocytes are unknown but a comparable situation exists with respect to chemical induction of ALA-synthase in liver $(11,15)$.

The deficient induction of URO-synthase in AIP lymphocytes was equivalent in individuals in whom the disease was in exacerbation and in remission as well as those in whom the gene defect had never been expressed clinically. There was no correlation in the extent of URO-synthase induction and the amount of ALA or PBG excreted into urine in AIP subjects. Similarly, the URO-synthase deficiency of erythrocytes and skin fibroblasts from AIP gene carriers does not distinguish those in whom the disorder is active from those in whom the gene defect has remained completely latent. Thus, it is clear that clinical expression of the AIP gene defect must be the result of the interaction of other factors including nutritional, endocrine, environmental, and metabolic ones with the primary genetic abnormality, URO-synthase deficiency (5, 21-24).

Few studies have been made of the porphyrin-heme biosynthetic pathway in human lymphocytes. Saillen et al. (25) reported that such lymphocytes are capable of generating porphyrins from ALA. They observed that incubation of cells with PHA for $96 \mathrm{~h}$ considerably increased porphyrin formation from this precursor-a 
finding consistent with our own. However, they used a crude buffy coat preparation of cells, and their findings were difficult to interpret because the cell fraction was significantly contaminated with red cells and granulocytes. Josephson et al. (26), using a slightly more refined technique to isolate lymphocytes, also reported that human lymphocytes produce porphyrins when incubated with ALA for $48 \mathrm{~h}$. In contrast to Saillen's finding, they found no effect of PHA on porphyrin formation from ALA. This discrepancy can be readily explained by the fact that a significant increase of porphyrin accumulation from ALA in response to mitogens takes place only after the $72 \mathrm{nd} h$ of incubation and reaches a maximum at the 96 th $\mathrm{h}$. In this report we prepared lymphocytes that were completely freed from platelets by the use of defibrinated blood and freed from erythrocytes as the result of differential hemolysis with ammonium chloride-Tris- $\mathrm{KHCO}_{3}$. This method removed from the final incubation preparation red cells which are highly active in converting ALA to porphyrin. This permitted us to follow URO-synthase activity or porphyrin formation from ALA in the cultured lymphocytes without interference by such activities present in the erythrocytes.

The level of PROTO formation from ALA in cultured AIP lymphocytes was also indistinguishable from the level of PROTO formation in normal lymphocytes until 3 days after the treatment with the mitogens. The mean PROTO formation in 4-day mitogen-stimulated AIP cell cultures was approximately $50 \%$ compared with that of normal cells, thus being proportional to the deficient induction of URO-synthase activity. PROTO accumulation was facilitated by the use of a chemically defined medium (9) and was considerably enhanced when CaMgEDTA, an inhibitor of ferrochelatase, was added to the cultures on the 4th day after the addition of the mitogens. This finding suggests that a substantial fraction of PROTO synthesized from ALA may normally be utilized to form heme unless an inhibitor of ferrochelatase is added to the cultured lymphocytes. The addition of CaMgEDTA at the initiation of culture was found inhibitory to mitogen-induced transformation of lymphocytes, supporting the suggested role of metals in this process (27).

Mitogen stimulation of PROTO formation or UROsynthase activity is a specific action of mitogens in lymphocytes, because these agents did not increase porphyrin formation in either normal or AIP skin fibroblasts. This finding is consistent with those of Hodgson and Hell (28) who found no increase in synthesis of DNA in cultures of human skin fibroblasts incubated with PHA.

Whereas PHA is presumed to stimulate mainly $\mathrm{T}$ lymphocytes $(29,30)$, EB virus is considered to transform mainly B lymphocytes because only B lymphocytes have receptors for the virus and all of the virus-transformably lymphoid cell lines have B-cell markers $(30,31)$. URO-synthase activity and PROTO formation in EB virus-transformed AIP lymphocytes were also decreased approximately $50 \%$ compared with the values in EB-infected normal cells. These findings suggest, though they do not conclusively prove, that the induction of URO-synthase follows cellular transformation in both $\mathrm{T}$ and $\mathrm{B}$ lymphocytes.

In contrast to earlier findings in AIP liver cells, ALA-synthase activity in AIP lymphocytes is not elevated when compared with the enzyme levels in normal cells. Moreover the induction of ALA-synthase in response to mitogen treatment is only two- to threefold compared with the marked induction of URO-synthase (10 30-fold). The normal level of ALA-synthase found in cultured AIP lymphocytes, together with deficient URO-synthase, is similar to the situation found in cultured AIP skin fibroblasts where normal levels of ALA-synthase are also observed despite the presence of a concurrent deficiency of URO-synthase $(8,10)$. It has been suggested on the basis of the latter observation that the regulation of ALA-synthase production in fibroblasts may be different from that in liver cells (10). Alternatively, there may not be any reduction in heme content of AIP fibroblasts as is thought to exist in AIP liver cells (32). No deficiency of heme content was demonstrated in mitogen-stimulated AIP lymphocytes in this study even though URO-synthase induction was defective: therefore, the secondary induction of ALA-synthase would not be expected. With respect to this question it should be recalled that completely latent AIP gene carriers show normal urinary levels of ALA and PBG, despite the fact that they also have URO-synthase deficiency similar to that of clinically manifest AIP patients. Thus, they presumably also have normal levels of ALAsynthase in their liver cells, in keeping with the combination of similar findings (low URO-synthase, normal ALA-synthase) in AIP fibroblasts and mitogenstimulated lymphocytes.

Recently, Grandchamp et al. (33) reported that a deficiency of coproporphyrinogen oxidase can be demonstrated in unstimulated lymphocytes obtained from patients with hereditary coporporphyria, another autosomal-dominant porphyric disorder in man. We have demonstrated that the ferrochelatase deficiency of erythropoietic protoporphyria can also be elicited in mitogen-stimulated lymphocytes when cells are incubated with ALA but without EDTA (19). In the absence of this inhibitor of ferrochelatase, erythropoietic protoporphyria lymphocytes accumulate significantly greater amounts of PROTO compared with normal cells, reflecting the genetic defect involving ferrochelatase in this disease. Thus, three of the four porphyric disorders of man which are known to be transmitted in autosomal-dominant fashion can now be identified by the use of lymphocytes in culture.

Mitogen-treated lymphocytes provide a cell prepara- 
tion in which striking increases in metabolic activities related to DNA, RNA, and protein synthesis are occurring; therefore, it is possible to examine the rate of synthesis of a specific protein in contrast to other cell types, such as erythrocytes or fibroblasts, in which such marked metabolic activation is not inducible. In this study, the specific activity of URO-synthase increased markedly in response to mitogens, but the level of induced enzyme synthesis in AIP lymphocytes was only $50 \%$ of that found in normals.

This finding clearly establishes that the rate of production of normal URO-synthase in AIP cells is defective. Other data indicate that the URO-synthase of AIP cells has normal physicochemical properties $(3,5)$. These facts suggest that URO-synthase in AIP cells is structurally normal, and that its decreased level is caused by a deficiency in the production of a normal enzyme. This situation is analogous to the thalassemic syndromes where decreased globin synthesis is a result of a decrease in normal globin peptide formation rather than a result of the production of abnormal globins (34). Whether the decreased synthesis of normal UROsynthase in AIP cells is the result of decreased transcription of a messenger RNA or of an unstable messenger RNA as is speculated in thalassemia (34), is not known. At any rate, although the question cannot be conclusively resolved until the amino acid sequence of URO-synthase is determined, the results of this study do provide evidence that the AIP gene defect may represent a gene mutation regulating the rate of synthesis of a normal enzyme rather than a mutation leading to the production of a structurally abnormal protein

\section{ACKNOWLEDGMENTS}

We are grateful to Dr. Karl E. Anderson of The Rockefeller University Hospital for clinical assistance and to Dr. Arthur E. Greene, Institute for Medical Research, Camden, N. J., for preparing EB virus-infected lymphocytes. The excellent technical assistance of Mrs. C. Chang, Mr. P. Larkin, and Mr. S. N. Feltham and the secretarial assistance of Mrs. H. Robinson are gratefully acknowledged.

Special thanks are given to Dr. Leonard C. Harber, Professor and Chairman of the Department of Dermatology, Columbia University College of Physicians and Surgeons, New York, for providing essential support for Dr. Zalar in this study through U. S. Public Health Service training grant T32-AM 07171-02. This study was supported in part also by U. S. Public Health Service grant ES-01055, American Cancer Society grant BC-180A, and National Foundation grant I-350.

\section{REFERENCES}

1. Strand, J., B. F. Felsher, A. G. Redeker, and H. S. Marver. 1970. Enzymatic abnormality in heme biosynthesis in acute intermittent porphyria. Decreased hepatic conversion of porphobilinogen to porpyrins and increased delta aminolevulinic acid synthetase activity. Proc. Natl. Acad. Sci. U. S. A. 67: 1315-1320.

2. Miyagi, K., R. Cardinal, I. Bossenmaier, and C. J. Watson. 1971. The serum porphobilinogen and hepatic por- phobilinogen deaminase in normal and porphyric individuals. J. Lab. Clin. Med. 78: 683-695.

3. Strand, L. J., U. A. Meyer, B. F. Felsher, A. G. Redeker, and H. S. Marver. 1972. Decreased red cell uroporphyrinogen I synthetase in intermittent acute porphyria.J. Clin. Invest. 51: 2530-2536.

4. Meyer, U. A., L. J. Strand, M. Doss, C. A. Rees, and H. S. Marver. 1972. Intermittent acute porphyria: demonstration of a genetic defect in porphobilinogen metabolism. $N$. Engl. J. Med. 286: 1277-1282.

5. Sassa, S., S. Granick, D. R. Bickers, H. L. Bradlow, and A. Kappas. 1974. Studies in porphyria. III. A microassay for uroporphyrinogen I synthetase, one of three abnormal enzyme activities in acute intermittent porphyria, and its application to the study of the genetics of this disease. Proc. Natl. Acad. Sci. U. S. A. 71: 732-736.

6. Magnussen, C. R., J. B. Levine, J. M. Doherty, J. O. Cheeseman, and D. P. Tschudy. 1974. A red cell enzyme method for the diagnosis of acute intermittent porphyria. Blood. 44: 857-868.

7. Bickers, D. R., L. Keogh, A. B. Rifkind, L. C. Harber, and A. Kappas. 1977. Studies in porphyria. VI. Biosynthesis of porphyrins in mammalian skin and in the skin of patients with selected types of porphyria.J. Invest. Dermatol. 68: 5-9.

8. Meyer, U. A. 1973. Intermittent acute porphyria. Clinical and biochemical studies of disordered heme biosynthesis. Enzyme (Basel). 16: 334-342.

9. Sassa, S., G. Solish, R. D. Levere, and A. Kappas. 1975. Studies in porphyria. IV. Expression of the gene defect of acute intermittent porphyria in cultured human skin fibroblasts and amniotic cells. Prenatal diagnosis of the porphyric trait. J. Exp. Med. 142: 722-731.

10. Bonkowsky, H. L., D. P. Tschudy, E. C. Weinbach, P. S. Ebert, and J. M. Doherty. 1975. Porphyrin synthesis and mitochondrial respiration in acute intermittent porphyria: studies using cultured human fibroblasts. J. Lab. Clin. Med. 85: 93-100.

11. Sassa, S., and A. Kappas. 1977. Induction of $\delta$ aminolevulinate synthase and porphyrins in cultured liver cells maintained in chemically defined medium: permissive effects of hormones on the induction process. J. Biol. Chem. 252: 2428-2436.

12. Lowry, O. H., A. Rosebrough, A. L. Farr, and R. J. Randall. 1951. Protein measurement with the Folin phenol reagent. J. Biol. Chem. 193: 265-275.

13. Tanford, C., and G. L. Roberts, Jr. 1952. Phenolic hydroxyl ionization in proteins. I. Bovine serum albumin. J. Am. Chem. Soc. 74: 2509-2515.

14. Granick, S., S. Sassa, J. L. Granick, R. D. Levere, and A. Kappas. 1972. Assays for porphyrins, $\delta$-aminolevulinicacid dehydratase, and porphyrinogen synthetase in microliter samples of whole blood. Applications to metabolic defects involving the heme pathway. Proc. Natl. Acad. Sci. U. S. A. 69: 2381-2385.

15. Granick, S., P. Sinclair, S. Sassa, and G. Grieninger. 1975. Effects by heme, insulin, and serum albumin on heme and protein synthesis in chick embryo liver cells cultured in a chemically defined medium, and a spectrofluorometric assay for porphyrin composition.J. Biol. Chem. 250: 92159225 .

16. Sassa, S., S. Granick, D. R. Bickers, R. D. Levere, and A. Kappas. 1973. Studies on the inheritance of human erythrocyte $\delta$-aminolevulinate dehydratase and uroporphyrinogen synthetase. Enzyme (Basel). 16: 326-337.

17. Sassa, S. 1976. Sequential induction of heme pathway enzymes during erythroid differentiation of mouse Friend leukemia virus-infected cells. J. Exp. Med. 143: 305-315.

18. Baudhuin, P., H. Beaufay, Y. Rahman-Li, O. Z. Sellinger, 
S. Wattiaux, P. Jacques, and C. deDuve. 1964. Tissue fractionation studies. XVII. Intracellular distribution of monoamine oxidase, aspartate amino-transferase, alanine aminotransferase, D-amino acid oxidase, and catalase in rat liver tissue. Biochem. J. 92: 179-184.

19. Sassa, S., G. L. Zalar, and A. Kappas. 1977. Expression of the gene defects of acute intermittent porphyria (AIP) and erythropoietic protoporphyria (EPP) in mitogen-stimulated lymphocytes. J. Clin. Chem. Clin. Biochem. (Berl.). In press.

20. Sassa, S., R. D. Levere, G. Solish, and A. Kappas. 1974. Studies on the porphyrin-heme biosynthetic pathway in cultured human amniotic cells. J. Clin. Invest. 53: 702.

21. Kappas, A., S. Sassa, S. Granick, and H. L. Bradlow. 1974. Endocrine-gene interaction in the pathogenesis of acute intermittent porphyria. Res. Publ. Assoc. Res. Nerv. Ment. Dis. 53: 225-237.

22. Kappas, A., H. L. Bradlow, P. N. Gillette, and T. F. Gallagher. 1972. Studies in porphyria. I. A defect in the reductive transformation of natural steroid hormones in the hereditary liver disease, acute intermittent porphyria. J. Exp. Med. 136: 1043-1053.

23. Bradlow, H. L., P. N. Gillette, T. F. Gallagher, and A. Kappas. 1973. Studies in porphyria. II. Evidence for a deficiency of steroid $\Delta^{4}-5 \alpha$-reductase activity in acute intermittent porphyria. J. Exp. Med. 138: 754-763.

24. Kappas, A., H. L. Bradlow, D. R. Bickers, and A. P. Alvares. 1977. Induction of a deficiency of steroid $\Delta^{4}-5 \alpha$-reductase activity in liver by a porphyrinogenic drug. J. Clin. Invest. 59: 159-164.

25. Saillen, R., E. Jéquier, and A. Vannotti. 1969. Porphyrin synthesis by the phytohemagglutinin-transformed lymphocytes in vitro. J. Reticuloendothel. Soc. 6: 175-183.
26. Josephson, A. S., R. D. Levere, I. Lowenthal, F. Swerdlow, and M. Ginsberg. 1972. Porphyrin synthesis by cultured lymphocytes. Blood. 39: 568-574.

27. Chesters, J. K. 1972. The role of zinc ions in the transformation of lymphocytes by phytohemagglutinin. Biochem. J. 130: 133-139.

28. Hodgson, C., and E. Hell. 1966. Failure of phytohemagglutinin to effect epidermal DNA synthesis. Br. J. Dermatol. 78: 525-527.

29. Stobo, J., A. S. Rosenthal, and W. E. Paul. 1972. Functional heterogeneity of murine lymphoid cells. I. Responsiveness to and surface binding of concanavalin $\mathrm{A}$ and phytohemagglutinin. J. Immunol. 108: 1-17.

30. Janossy, G., and M. Greaves. 1975. Functional analysis of murine and human B lymphocyte subsets. Transplant. Rev. 24: $177-236$.

31. Greaves, M. F., G. Brown, and A. B. Rickinson. 1975. Epstein-Barr virus binding sites on lymphocyte subpopulations and the origin of lymphoblasts in cultured lymphoid cell lines and in the blood of patients with infectious mononucleosis. Clin. Immunol. Immunopathol. 3: $514-524$.

32. Watson, C. J., C. A. Pierach, I. Bossenmaier, and R. Cardinal. 1977. Postulated deficiency of hepatic heme and repair by hematin infusions in the "inducible" hepatic porphyrias. Proc. Natl. Acad. Sci. U. S. A. 74: 2118-2120.

33. Grandchamp, B., and Y. Nordman. 1977. Decreased lymphocyte coproporphyrinogen III oxidase activity in hereditary coproporphyria. Biochem. Biophys. Res. Commun. 74: 1089-1095.

34. Benz, E. J., Jr., and B. G. Forget. 1975. The molecular genetics of the thalassemia syndrome. Prog. Hematol. 9: $107-155$. 